\title{
Isolation and Screening of Cellulose Degrading Bacteria in Kitchen Waste and Detecting Their Degrading Potential
}

\author{
Manmeet Kaur ${ }^{1}$ and Dr. S. Arora ${ }^{2}$ \\ Department of Civil Engineering, PEC University of Technology, Chandigarh, \\ 1 M.E Environment Engg.,.Final year Student, PEC Chandigarh \\ 2Associate Professor, Post Graduate Department of Civil Engineering, PEC, Chandigarh \\ India
}

\begin{abstract}
The present paper investigates cellulose degrading bacteria present in kitchen waste for highest cellulase activity and growth of bacteria at optimum temperature and $\mathrm{pH}$. Sample was collected from domestic kitchen waste and bacterial strains were isolated using nutrient agar media. Enrichment technique was used for isolating CDB (cellulose degrading bacteria) strains. The objective of research was to utilize effective bacteria for degrading complex polymer cellulose into simpler sugars like glucose under optimum working conditions. Out of 21 isolated bacterial strains, only four were having effective cellulose degrading bacteria. These four isolates were screened for qualitative estimation through Congo red dilution assay and quantitatively tested by DNS method (Miller, 1959). The optimum $\mathrm{pH}$ and temperature for most potent isolate was recorded as 7 and $35^{\circ} \mathrm{C}$ respectively. It was concluded that these findings were in accordance with previous results. These optimum working conditions were recommended for biomass utilization.
\end{abstract}

Keywords: Kitchen waste, Cellulose degrading bacteria, optimization, solid waste

\section{Introduction}

Kitchen Waste forms a significant part of domestic waste. Food waste is an unwanted raw or cooked food discarded during or after food preparation that is no longer fit for consumption or desirable (N.Jean et $a l, 2009)$. Toxic Links at New Delhi conducted a survey in May 2002 and prepared a fact file on waste which stated that about 0.1 million ton of municipal solid waste is generated in India every day. So, annual production reaches approximately 36.5 million tones. There is a large variety of micro organisms present in waste such as bacteria, fungi, protozoa et al. In this research study, main focus was on cellulose degrading bacteria in food waste. Cellulolytic microorganisms are those that degrade cellulose present in waste into other useful products. These play an important role in the biosphere by reducing complex polymer cellulose into various economically important products like monomeric sugars, microbial biomass proteins, compost, antibiotics etc, to everyday use for man. Annual production of cellulose is estimated to be 4.0x10 tons ( A. Singh et al, 1995).

Biodegradation is breakdown of organic contaminants occurring due to production of extracellular enzymes by microorganisms. These contaminants can be considered as the substrate or microbial food source (Maier et al., 2000). Enzymes have also been an interesting topic of research all over the world considering their broad range of physiological, industrial and analytical applications; especially from microorganisms due to their broad biochemical diversity, feasibility of mass culture and ease of genetic manipulation (Chakrabortya et al., 2009). The optimization of the development of any fermentation process, particularly physical and chemical parameters are of primary importance, owing to their impact on the economy and practicability of the process (Wenster-Botz, 2000). Worldwide interest in microbiological decomposition of cellulose is still as strong as when it started more than three decades ago. Cellulose degrading bacteria have been isolated by Han and Srinivasan (1968), Kauffmann et al (1976), Thayer and Murray (1977), Steward and Leatherwood (1976) based on enrichment culture technique utilizing different sources of carbon(Leticia M Coronel, 1986).

Cellulose consists mainly of long polymers of $\beta$ 1-4, linked glucose units and forms a crystalline structure (Shallom \& Shoham, 2003). Cellulase enzymes, which can hydrolyze cellulose forming glucose and other commodity chemicals, can be divided into three types: endoglucanase (endo-1, 4- $\beta$-D-glucanase); cellobiohydrolase or exoglucanase (exo-1, 4- $\beta$-D-glucanase) and $\beta$-glucosidase (1,4- $\beta$-D-glucosidase) (Li et al., 2006; Gao et al., 2008). Cellulases are important industrial enzymes and find applications in several industrial processes (Hanif et al., 2004; Jamil et al., 2005). Researchers have strong interests in cellulases because of their applications in industries of starch processing, grain alcohol fermentation, malting and brewing, extraction of fruit and vegetable juices, pulp and paper industry, and textile industry (Gao et al., 2008; Zhou et al., 2008).

The purpose of this work was basically to examine the possible utilization of cellulose degrading bacteria in kitchen waste for highest cellulase activity and bacterial growth at optimum working conditions such as $\mathrm{pH}$ and temperature. This purpose was achieved through different steps; isolation of cellulose degrading 
bacterial strains from kitchen wastes; selection of the most potent isolate producing cellulase activity; and optimization of working conditions affecting glucose biosynthesis by the preselected isolate.

\section{Materials And Methods}

\section{Culture media:}

Nutrient agar medium: This medium was used for obtaining auxenic culture. It has main composition of $0.5 \%$ Peptone; $0.3 \%$ beef extract/yeast extract; $1.5 \%$ agar; $0.5 \% \mathrm{NaCl}$ in distilled water and $\mathrm{pH}$ adjusted to neutral (6.8) at $25^{\circ} \mathrm{C}$.

Enrichment of cellulolytic bacteria was achieved in mineral salt solution of (in $\mathrm{g} / \mathrm{l}$ ): $\mathrm{NaCl}, 6.0 ;\left(\mathrm{NH}_{4}\right)_{2} \mathrm{SO}_{4}, 1.0 ; \mathrm{KH}_{2} \mathrm{PO} 4,0.5 ; \mathrm{K}_{2} \mathrm{HPO}_{4}, 0.5 ; \mathrm{MgSO}_{4}, 0.1 ; \mathrm{CaCl}_{2}, 0.1$ and supplemented with $0.1 \% \mathrm{CMC}$ as cellulose source.

\section{Sample Collection}

Sample was collected directly from waste receiving dustbin of domestic kitchen in many replicates. Pre -sterilized screw cap glass vials of $15 \mathrm{ml}$ capacity were used for collection purpose. Randomly selected one $\mathrm{cm}^{2}$ blocks of waste patch were scrapped with scapula and collected in separate vials and these were brought to laboratory for isolation of cellulose degrading bacteria.

\section{Isolation of Bacterial strains}

Streaking plate method was used for obtaining pure bacterial strain. After 21 bacterial strains were isolated, the one with cellulose degrading ability were determined using Enrichment technique.

\section{Screening of CDB strains}

Isolated cellulose degrading bacterial strains were screened for determination of highest cellulase activity. Quantitative assay using Congo red Dilution assay (Apun et al., 2000) was performed where zone of clearance was observed visually by staining plate with $0.1 \%$ congo red for 15 minute and destained with $1 \mathrm{M}$ $\mathrm{NaCl}$. Diameter of clear zone was measured in zone of clearance where cellulase activity occurred.

Qualitative assay was performed by determining the amount of reducing sugars liberated by using Dinitrosalicyclic Acid (DNS) method (Miller 1959). A cellulolytic bacteria was recorded to have highest cellulase activity and selected for optimization of production of cellulase enzyme.

\section{Determination of optimal $\mathrm{pH}$, Temperature}

Preselected isolate was dispensed in test tubes containing mineral salt broth medium with $0.1 \%$ cellulose and was adjusted from $\mathrm{pH} 5$ to 8 . It was incubated at $37^{\circ} \mathrm{C}$ for $96 \mathrm{~h}$. Following the incubation, growth of the cultures was measured by observation of the optical density at $560 \mathrm{~nm}$.

Same procedure was followed for determining bacterial growth at varying temperature. Tubes were incubated at different temperatures $30,35,40$ and $45^{\circ} \mathrm{C}$ for $96 \mathrm{~h}$.

\section{Results And Discussions}

\section{Isolation and screening of CDB Strains}

Out of 21 isolated bacteria, four isolates (CDB1, CDB 12, CDB18, and CDB 20) were screened for showing noticeable cellulase activity.

Highest cellulase activity was recorded by CDB12. Enzymatic activity was determined through congo red test where zone of clearance was measured in $\mathrm{mm}$ and compared with standard cellulase. This indicated that these cellulolytic bacterial strains utilized the available sources of cellulose present in waste and carried out their degradation.

Quantitative test of these isolate showed highest enzymatic activity in CDB 18 with $24 \mathrm{U} / \mathrm{ml}$.

The diameter of zone of clearance observed in congo red dilution assay did not predicate the amount of cellulase activity occurred in sample. According to report published in 2000, out of number of thermo tolerant bacterial isolates grown on CMC agar, an isolate CMU 4-4 recorded smaller clear zone than other strains but it had highest enzymatic activity ( Krootdilaganandh 2000).

\section{Optimum pH and Temperature of CDB isolate}

The highest bacterial growth was found at $\mathrm{pH}$ 7. The growth was also recorded at other $\mathrm{pH}$ values i.e 5 to 8 . $\mathrm{Lu}(2005)$ has reported that organisms can grow well at a $\mathrm{pH}$ ranging from 5.7 to 7.5.

The optimum temperature at which highest bacterial growth was produced was $35^{\circ} \mathrm{C}$. The growth of bacteria also occurred at other temperature values which showed that CDB strains are tolerant to both higher and lower temperature. 


\section{Conclusion}

The results from this research supported the general conclusion that introduction of cellulose degrading bacterial (CDB) strains is an advantageous tool of microbiology to support energy recovery from degraded ecosystems. Upon screening, only one isolate was found to have highest cellulase activity which was an indication of presence of cellulose decomposer that can break down large organic molecules into smaller molecules that can be used by the biotic community. This in turn will provide some medium to utilize renewable sources of energy with the help of micro organisms and processes they undergo during degradation of complex polymer to simpler sugars.

\section{Acknowledgement}

The authors are grateful to PEC University of Technology, Chandigarh for their cooperation and encouragement to carry out the work.

\section{References}

[1] A. Singh and K. Hayashi. Microbial cellulase, protein architecture, molecular properties and biosynthesis. Adv. Appli. Microbiol. 40:1-44 (1995)

[2] Apun K, Jong BC and Salleh MA. Screening and isolation of a cellulolytic and amylolytic Bacillus from sago pith waste. J Gen Appl Microbilo 2000; 46: 263-267.

[3] Chakrabortya S, Khopadea A, Kokarea C, Mahadika K, Chopadeb B (2009). Isolation and characterization of novel $\alpha$-amylase from marine Streptomyces sp. D1.J. Molecular Catalysis B: Enzymatic; 58: 17-23.

[4] Gao, J., H. Weng, D. Zhu, M. Yuan, F. Guan and Yu Xi. 2008. Production and characterization of cellulolytic enzymes from the thermoacidophilic fungal Aspergillus terreus M11 under solid state cultivation of corn stover. Bioresour. Technol., 99: 7623-7629

[5] Han, Y.W. and V.R. Srinivasan. (1968). Isolation and characterization of a cellulose utilizing bacterium. Appl. Microbiol., 16(18):1140-1145.

[6] Hanif, A., A. Yasmin and M.I. Rajoka. 2004. Induction, production, repression and de-repression of exoglucanase synthesis in Aspergillus niger. Bioresour. Technol., 94: 311-319.

[7] Jamil, A., S. Naim, S. Ahmed and M. Ashraf. 2005: Production of Industrially important enzymes using molecular approaches; cellulases and xylanases. In: Genetic resources and Biotechnology II, Volume Two, (Eds.): D. Thangadurai, T. Pullaiah, Pedro and A. Balatti. Regency publications, New Delhi.

[8] Kaufmann, A., J. Fegan, P. Doleac, C. Gainer, D. Wittich and A. Glann. (1976). Identification and characterization of a cellulolytic isolate. J. gen. Microbiol., 94: 405-408.

[9] Krootdilaganandh J. Isolation and selection of thermotolerant bacteria capable of producing cellulase. Chiang Mai: Chiang Mai University Press 2000; 20-21

[10] Leticia M Coronel, L. M. (1986). Isolation, Screeening and Characterisation of Cellulose utilising Bacteria. The Phillipines Journal Of Science, $115(3), 223-232$.

[11] Li, Y.H., M. Ding, J. Wang, G.J. Xu and F. Zhao. 2006. A novel thermoacidophilic endoglucanase, Ba-EGA, from a new cellulose degrading bacterium, Bacillus sp. AC-1. Appl. Microbiol. Biotechnol., 70: 430-436.

[12] Maier RM, Peper IL, Gerba CP (2000). Environment Microbiology, Academic Press.

[13] Miller GL (1959). Use of dinitrosalicylic acid reagent for determination of reducing sugar. Anal. Chem., 31: 426-428.

[14] Nathalie Jean-Baptiste,2009,People \& Food waste-The practice of everyday life;

[15] Reese E, Siu RGH, Levinson HS (1950). The Biological Degradation of Soluble Cellulose Derivatives and Its Relationship to the Mechanism of Cellulose Hydrolysis. J. Bact., 59: 485-497.

[16] Shallom, D. And Y. Shoham. 2003. Microbial Hemicellulases. Curr. Opin. Microiol., 6: 219-228.

[17] Stewart, B.J., and J.M. Leatherwood.(1976). Depressed synthesis of cellulase by cellulomonas. J. Bacteriol. ,128 (2):609-615.

[18] Wenster-Botz D (2000). Experimental design for fermentation media development: Statistical design or Global random search? J. Biosci. Bioeng.; 90 (5): 473-483.

[19] Zhou, J., Y.H. Wang, J. Chu, Y.P. Zhuang, S.L. Zhang and P. Yin. 2008. Identification and purification of the main components of cellulases from a mutant strain of Trichoderma viride T 100-14. Bioresour. Technol., 99: 6826-6833 